Stanistaw M. Królak Papieski Wydziat Teologiczny w Warszawie Sekcja św. Jana Chrzciciela

\title{
Wierność powołaniu - ksiądz Kazimierz Świątek (1914-2011)
}

\section{FIDELITY TO THE PRIESTLY VOCATION - PRIEST KAZIMIERZ ŚWIĄTEK (1914-2011)}

In the history of Catholic church the 20th century will be remembered as the age of martyrs. Many Christians bore witness of their fidelity to Christ by sacrificing their lives. In that terrifying time of test of fidelity however, there was a great number of people who did not suffered death because of their faith and yet they bore witness to Christ. Nowadays the combat against religion, faith and the Church still continues. The need to bear personal witness of fidelity to both Christ and personal vocation has been becoming much more imperious. Furthermore, testimonies that recently there are people who have proven that being faithful to Christ, even being faithful to the point of heroism, is possible are vital and needed. Kazimierz Świątek, archbishop, cardinal was one of these people. The article presents his family environment, path to priesthood and period of presbyterate.

Key words: catholicism, gulag, communism, witness, confessor, faithfulness to God, the priestly vocation, priesthood.

\section{Wprowadzenie}

Wiek XX zapisał się z pewnością w historii Kościoła katolickiego, jako wiek męczenników. Wielu z nich czeka na wyniesienie na ołtarze 
i przekazanie potomnym ich świadectw życia. Podobnie jak w czasach Ojców Apostolskich tysiące, setki tysięcy chrześcijan, poniosło śmierć z powodu wiary w Chrystusa. Szacuje się, że w dotychczasowej historii Kościoła zostało zabitych około 70 milinów wiernych, spośród których ponad 45 milionów zginęło w XX wieku ${ }^{1}$.

Po hekatombie ofiar I wojny światowej dzieło niszczenia cywilizacji chrześcijańskiej kontynuował system komunistyczny zbudowany w Rosji na filozofii Hegla, Marksa i Engelsa, przekształconej w ideologię przez Lenina i Stalina. System komunistyczny w swej destrukcji świata opartego na Bogu otrzymał wsparcie ze strony niemieckiego nazizmu. Tak jak w czasach patrystycznych wielu chrześcijan zaświadczyło ofiarą życia o wierności Chrystusowi. Bardzo wielu też uległo złu, ale w strasznych czasach próby wcale liczni byli także katolicy świeccy, zakonnicy, zakonnice, kapłani i biskupi, którzy nie ponieśli śmierci za wiarę, ale świadczyli o Chrystusie. Ich życie naznaczone było męczeństwem ponoszonym w miejscach kaźni, więzieniach, łagrach i obozach koncentracyjnych. Zasługują oni na tytuł „Wyznawców”.

Dzisiaj chrześcijanie nadal giną w wielu miejscach świata. Trwa także, podobnie jak w okresie sowieckiego komunizmu, tylko przy pomocy bardziej wyrafinowanych metod, walka z religią, wiarą i Kościołem. Jest ona skuteczna. Wiarę w Boga, pojmowanego zgodnie z tradycją katolicką, zastępuje konsumpcjonizm, obojętność na sprawy ducha lub różnego rodzaju spirytualizm. Wielu kapłanów ogarnia zniechęcenie, także dlatego, że część wiernych ulega „sączonym” opiniom, że kapłani tylko świadczą usługi religijne, że to ich zawód. Konieczność zatrzymania tej niszczącej tendencji staje się coraz pilniejsza. Coraz bardziej nagląca staje się potrzeba dawania osobistego świadectwa wierności Chrystusowi i osobistemu powołaniu. Zarazem potrzeba świadectw, że współcześnie są ludzie, którzy udowodnili, że dochowanie wierności Chrystusowi - niekiedy w stopniu heroicznym - jest możliwe. Jedną z takich osób był ks. Kazimierz Świątek, arcybiskup, kardynał, Metropolita Mińsko-Mohylewski, administrator apostolski diecezji pińskiej. W niniejszym artykule analizie poddane zostanie jego dzieciństwo, wiek młodzieńczy i czas prezbiteratu. W tym okresie życia Kazimierz Świątek pozostał wierny Chrystusowi w stopniu heroicznym. Czas sprawowania urzędu biskupiego będzie tematem mojej osobnej publikacji.

\footnotetext{
$1 \quad$ Por. World Christian Encyklopedia.Acomparative survey of churches andreligions in the modern world, vol. 1, New York 2001, s. 11; A. Socci, Mroki nienawiści. Męczeństwo chrześcijan XX wieku. Studium nietolerancji, Kraków 2003, s. 30, 152.
} 


\section{Dzieciństwo i lata młodzieńcze}

21 października 1914 roku Weronika Świątek, z domu Kromplewska, urodziła syna, którego ojcem był jej mąż Jan Świątek. Narodziny miały miejsce w Wałku, wówczas powiatowym mieście w guberni inflanckiej Cesarstwa Rosyjskiego. Szczęśliwemu ojcu nie było dane cieszyć się z narodzin syna, gdyż jako poddany cara Mikołaja II został zmobilizowany, aby walczyć na frontach trwającej wojny światowej. Chłopiec został ochrzczony w kościele Matki Boskiej Bolesnej w Rydze Historia Kościoła (w Wałku nie było wówczas kościoła). Pod nieobecność ojca dziecko do chrztu przedstawił brat matki Kazimierz Kromplewski. Po nim właśnie chłopiec otrzymał imię. Kazimierz był drugim synem Weroniki i Jana. Ich pierwszy syn, Edward, miał wówczas dwa lata².

Rodzina matki Kazimierza wywodziła się z Wileńszczyzny, natomiast ojca - z Pińczowa w Świętokrzyskiem³.

Weronika Kromplewska, drugie dziecko Antoniego i Urszuli z domu Szakalis (Szakalińska), urodziła się 22 października 1890 roku w miejscowości Zielona Łąka, w parafii Sołoki ${ }^{4}$ koło miejscowości Dukszty na Brasławszczyźnie, w ówczesnym powiecie Nowoaleksandrowskim ${ }^{5}$,

2 Archiwum prywatne autora (APSK), na podstawie zapisu rozmowy autora $\mathrm{z}$ ks. kard. K. Świątkiem. W księgach urodzonych miasta Ryga Kazimierz Świątek jest zarejestrowany w dniu 2 listopada 1914 roku pod numerem 1477, tamże, jako miejsce zamieszkania dziecka wpisane jest miasto Ryga (daty wg starego stylu). Na podstawie wypisu aktu urodzenia, fotokopia w posiadaniu autora. Por. także odpis aktu urodzenia wystawiony 9.09.1939 r. przez Dziekana Prużańskiego, archiwum prywatne ks. kard. K. Świątka (APKS), kopia w APSK. Matka wybrała inne imię dla swego syna, ale K. Kromplewski je zapomniał i przyjmujący do chrztu dziecko kapłan zasugerował, aby nadać chłopcu imię chrzestnego - informacja ks. kar. K. Świątka przekazana autorowi. Edward Świątek był lotnikiem, prawdopodobnie zginął w czasie bombardowania Terespola we wrześniu 1939 roku (inna wersja to rok 1944). Mimo usilnych starań ks. K. Świątka nie udało się odnaleźć grobu.

3 czerwca 2000 r. w pińczowskim kościele pw. św. Jana Apostoła i Ewangelisty ks. kard. K. Świątek odebrał akt nadania mu honorowego obywatelstwa miasta Pińczowa. „Witamy Cię całym sercem, gdyż przybyłeś, by spojrzeć na chrzcielnicę, gdzie Twój ojciec otrzymał dar chrztu" - mówił zwracając się do ks. kardynała biskup kielecki K. Ryczan. Por. „Biuletyn KAI”, 4.06.2000; Kard. Światek otrzymathonorowe obywatelstwo Pinczowa, depesza Katolickiej Agencji Informacyjnej nr 65346 nadana 4.06.200 r. o 12.49 kopia w APSK, http://system. ekai.pl/kair/?screen=depesza\&_scr_depesza_id_depeszy $=65346$.

Sołoki, historyczna miejscowość, centrum polowań władców Litwy, obecnie Solaksas na Litwie. 
gdzie jej rodzice gospodarzyli na kawałku ziemi ${ }^{6}$. W kościele parafialnym w Sołokach ochrzcił ją 28 października tegoż roku ks. Leowiszkiewicz ${ }^{7}$. Rodzina Kromplewskich wywodziła się z miejscowej zubożałej szlachty, która, tak jak wiele rodzin w tym czasie, straciła szlachectwo decyzją władz carskich ${ }^{8}$. Ponieważ warunki utrzymania były trudne, Antoni Kromplewski wraz z rodziną wyjechał do Wałku ${ }^{9}$ i podjął pracę na kolei ${ }^{10}$. Tam Weronika poślubiła Jana Świątka. Po wybuchu I wojny światowej Jan Świątek został zmobilizowany do armii rosyjskiej. Po przewrocie bolszewickim, pod koniec 1917 roku lub na początku 1918, rodzina Kromplewskich wraz z Weroniką Świątek i jej synami wyjechała najpierw na Ukrainę ${ }^{11}$, a następnie na Syberię

$6 \quad$ APSK, na podstawie relacji Urszuli Kromplewskiej zapisanej przez jej wnuka Romualda Kromplewskiego, w posiadaniu autora.

7 Zapis w księdze ochrzczonych parafii Sołoki z 1890 roku, lp 4. Księga znajduje się w Litewskim Państwowym Archiwum Historycznym (Lietuvos Valstydes Istoryjos Archyvas) w Wilnie. Fotokopia w APSK. Weronika Świątek zmarła w Opolu 25 marca 1981 roku.

Być może dlatego w księdze ochrzczonych rodzice Weroniki Świątek określeni są jako mieszczanie.

Wałk, niegdyś miasto w Inflantach nad rzeką Pedeli, w 1920 roku podzielone na część łotewską Valka i estońską Valga. Zachowała się fotografia domu, w którym mieszkali Kromplewscy ( w zbiorach prywatnych R. Kromplewskiego), ale nie udało się ustalić, w której części miasta się on znajdował. Wyjazd do Wałku musiał nastąpić przed 1893 rokiem, gdyż siostra Weroniki, Stanisława urodziła się w tym właśnie roku już w Wałku.

10 Zachowała się legitymacja służbowa A. Kromplewskiego, z której wynika, że pracował on jako „artielnej starosta”, czyli kierował grupą robotników naprawiających tory. Zbiory prywatne R. Kromplewskiego.

11 Według relacji Urszuli Kromplewskiej i Kazimierza Kromplewskiego zanotowanej przez Romualda Kromplewskiego były to miejscowości Siewiarkowa i Kupińsk, relacja w posiadaniu autora. Ksiądz E. Borowski w książce Wyższe Seminarium Duchowne Diecezji Pińskiej 1925-1939, Drohiczyn 2000, s. 144 podaje, że było to miasto Siebrekowa nad Donem, a następnie Borysoglebsk, gdzie rodzina mieszkała do 1917, a dopiero stąd przeniosła się do Kupińska i stamtąd w 1919 roku rodzina Kromplewskich wraz z Weroniką Świątek ijej synami została wywieziona na Syberię. Według tej wersji wyjazd z Wałku musiałby nastąpić zaraz po urodzeniu się Kazimierza. Wydaje się to jednak wątpliwe. W archiwum prywatnym R. Kromplewskiego znajduje się bowiem kolejowa legitymacja służbowa Antoniego Kromplewskiego wystawiona we wrześniu 1917 roku, gdzie jest napisane, że pracuje on jako „arielnyj starosta” na Północno-Zachodniej Kolei. O pobycie rodziny Kromplewskich w Wałku lub okolicach w 1917 roku świadczą zachowane dwie książeczki oszczędnościowe wystawione jedna 13 stycznia 1917, druga 14 września 1917 roku w miejscowości Womar (w pobliżu Wałku w kierunku na Rygę): jedna na Kazimierza Kromplewskiego druga na Antoniego Kromplewskiego. Są w nich pieczątki wkładów pieniężnych z datami: 
w okolice Tomska ${ }^{12}$. Na Syberii warunki życia Weroniki i jej synów były bardzo trudne. Brat Weroniki pracował jako dróżnik na kolei i z nim zamieszkała Weronika z synami. Kardynał Świątek wspominał, że jako kilkuletnie dziecko chodził na stację i próbował sprzedać podróżnym dwa, trzy jabłka, aby zdobyć kilka kopiejek ${ }^{13}$.

W tym czasie szeregowiec Jan Świątek walczył o Polskę w Pierwszym Pułku Legionów; 20 kwietnia 1919 roku zginął, broniąc Wilna przed bolszewikami. Spoczął na cmentarzu wojskowym na Rossie ${ }^{14}$.

Po pokoju ryskim, gdy tylko pojawiła się możliwość powrotu do Polski, rodzina Świątków i Kromplewskich rozpoczęła starania o powrót z Syberii. Granicę polsko-sowiecką w Stołpcach przekroczyli 3 maja 1921 roku $^{15}$. Pojechali do Dukszt, gdyż tam mieszkała siostra babci Kazimierza. Tam też w kościele pw. św. Stanisława Kostki Kazimierz

13.12.17; 23.11.17 i 19,12,17. Książeczki znajdują się w archiwum prywatnym R. Kromplewskiego.

APSK, na podstawie zapisu rozmowy autora z ks. kar. K. Świątkiem, przy czym ks. kard. K. Świątek zapamiętał ten wyjazd jako zesłanie. Według innych relacji m.in. Urszuli, Stanisławy i Kazimierza Kromplewskich, zanotowanych przez R. Kromplewskiego, wyjazd związany był raczej z szukaniem lepszych warunków życia. Kilkoro osób z rodziny pracowało na kolei transsyberyjskiej, m.in. Kazimierz, z którym mieszkała jego siostra Weronika z synami. Były to okolice stacji kolejowych Szyszyno i Jurga.

13 APSK, na podstawie zapisu rozmowy autora z ks. kar. K. Świątkiem. O głodzie świadczy takie zdarzenie: młody Kazimierz miał sprzedać jabłka, ale sam ich nie dostawał dojedzenia. Któregoś dnia nie wytrzymał i aby poczuć smakjabłka wbił w nie zęby, a następnie staranie wytarł, i próbował sprzedać. Znalazł się kupiec, ale niestety zauważył ślad zębów. Jabłka nie kupił, a chłopiec dostał ostrą reprymendę od matki.

14 APSK, grób nr 58, na podstawie dokumentacji własnej autora i rozmowy autora z ks. kar. K. Świątkiem. Por. J. Bohdanowicz Mauzoleum Marszałka i cmentarz żotnierski na Rossie, Warszawa 2007, s. 9.

15 Taką datę zapamiętał ks. kar. K. Świątek. Jednakże we własnoręcznie napisanym dla celów ustalenia emerytury wykazie Stanisława Kromplewska podaje, że pracowała na Syberii od 1 czerwca 1919 roku do 20 maja 1921 roku, a „od 20 maja 1921 roku do 1 czerwca 1922 roku trwała repatriacja”. Obywatelstwo polskie rodzinie Kromplewskich nadał 21 lipca 1923 roku starosta brasławski. Oryginał nadania w archiwum prywatnym R. Kromplewskiego. W Archiwum Akt Nowych w Warszawie, w zbiorze dokumentów polskiej straży granicznej z tego okresu, brak informacji dotyczących rodziny Świątków i Kromplewskich. Ksiądz dr E. Borowski w Wyższe Seminarium..., op. cit., s. 145 podaje, że rodzina Świątków w czerwcu 1921 roku przybyła z Syberii do Zubnicy koło miasta Wołdaj, a następnie do Petersburga, gdzie dopiero 1 maja 1922 roku otrzymała zgodę na repatriację, a 10 maja 1922 roku przybyła do Baranowicz, skąd po dwóch dniach pojechała do Dukszt. W rozmowach z autorem niniejszej pracy ks. kard. K. Świątek nigdy nie wspominał, że z rodziną mieszkał w Petersburgu. Również pytany o to przez autora R. Kromplewski oświadczył: „Rodzina 
Historia Kościoła

Świątek i jego brat Edward przystąpili do Pierwszej Komunii Świętej. Po pięciu latach, w lecie, prawdopodobnie w lipcu 1926 roku, Weronika Świątek z synami zamieszkała w Baranowiczach w domku przy ówczesnej ulicy Szosowej pod numerem $236^{16}$.

To miasto stanie się miastem rodzinnym późniejszego Kardynała ${ }^{17}$.

W 1922 roku Kazimierz Świątek rozpoczął naukę w szkole powszechnej w Duksztach, a od 1926 roku kontynuował ją w Baranowiczach. Po ukończeniu w 1928 roku szkoły powszechnej został uczniem Gimnazjum im. Tadeusza Rejtana w tymże mieście ${ }^{18}$.

Warunki życia rodziny Świątków były bardzo trudne. „Mama była krawcową, co dało się uszyć, to z tego żyliśmy. Boże, ile razy byliśmy bez obiadu, bez śniadania. Gimnazjum. Jak ja je skończyłem?!... Biegałem po całym mieście, jak tylko mogłem gdzieś udzielić korepetycji, żeby zarobić troszkę pieniążków. Uczyłem się na piątki, to nauczyciele też podpowiadali gorzej się uczącym, by poprosili mnie o korepetycje"19. Ksiądz kard. Świątek podkreślał, że matce zawdzięczał bardzo dużo. Bieda nie przeszkodziła jej nauczyć synów poczucia własnej godności. Godność osobista i honor były dla Kazimierza Świątka

nigdy nie mieszkała w Petersburgu". W tamtejszym szpitalu zmarł natomiast A. Kromplewski.

APSK, na podstawie rozmowy autora z ks. kar. K. Świątkiem. W latach dziewięćdziesiątych XX wieku drewniany dom, w którym mieszkała rodzina Świątków jeszcze istniał i autor niniejszej rozprawy dom oglądał. Ksiądz kard. wspominał, że Antoni Kromplewski zachorował w czasie powrotu z Syberii w czasie postoju w jakimś mieście już po przekroczeniu Uralu. Umieszczony został w szpitalu kolejowym w Leningradzie, w którym zmarł tuż przed Bożym Narodzeniem. Pochował go na cmentarzu przy Newskim Prospekcie Kazimierz Kromplewski ustawiając na grobie drewniany katolicki krzyż. Ksiądz kard. wraz z rodziną tuż przed wyjazdem do Polski odwiedził grób swego dziadka. Powtórnie pojechał do Leningradu po II wojnie światowej i odnalazł grób ze stojącym jeszcze krzyżem. Decyzja o wyjeździe do Baranowicz wynikała z nadziei na lepsze warunki utrzymania w dynamicznie rozwijającym się mieście. Kilka lat później w Baranowiczach zamieszkał i pracował na kolei Kazimierz Kromplewski oraz Stanisława Kromplewska. Relacja R. Kromplewskiego przekazana autorowi.

Baranowicze, które dopiero w 1919 roku otrzymały prawa miejskie, rozwijały się w tym czasie niezwykle intensywnie i wkrótce stały się największym miastem województwa nowogródzkiego, ważnym ośrodkiem przemysłowym, kulturalnym i religijnym regionu. W 1938 roku uruchomiono tu jedną z najnowocześniejszych rozgłośni Polskiego Radia. Por. Rocznik polityczny i gospodarczy 1939, PAT Warszawa 1939, s. 328.

APSK, na podstawie zapisu rozmowy autora z ks. kard. K. Świątkiem.

APSK, zapis rozmowy autora z ks. kard. K. Świątkiem. Ksiądz kard. K. Świątek w czasie rozmów z autorem był bardzo wstrzemięźliwy, gdy mówił o warunkach życia jego rodziny w Baranowiczach. Jednak na podstawie kilku rozmów, autor ma podstawy sądzić, że były one bardzo ciężkie. 
wartościami niepodlegającymi żadnym kompromisom. Od młodości taka postawa wymagała wyrzeczeń. „Wdzięczny jestem mamie, że mnie nauczyła poczucia honoru"20.

Weronika Świątek nie pobłażała chłopcom - wychowywała ich na dobrych Polaków i katolików. Postawę patriotyczną Kazimierza i Edwarda kształtowały także żywa pamięć o ojcu, który walczył w Legionach, szkoła średnia, w której kształtowanie patriotycznych postaw młodzieży należało do podstawowych celów wychowawczych, oraz Historia ówczesna specyfika społeczna Baranowicz. Było to miasto garnizonowe, w którym stacjonowało kilka jednostek wojskowych - m.in. tu było dowództwo Nowogródzkiej Brygady Kawalerii i Pułk KOP „Baranowicze". W mieście znajdował się też Grób Nieznanego Żołnierza ${ }^{21}$. Defilady i uroczystości z okazji świąt państwowych od dziecka wywarły silne piętno na Kazimierzu Świątku. Obaj synowie Weroniki Świątek byli ministrantami i codziennie rano biegali do kościoła Podwyższenia Krzyża Świętego, aby służyć do Mszy św. ks. Kazimierzowi Bohuszowi. Ksiądz kardynał Kazimierz Świątek tak to zapamiętał:

Codziennie służyłem mu do Mszy Świętej. O szóstej rano odprawiał Mszę Świętą i biegałem ze swoim braciszkiem, żeby mu usłużyć. Kościół oczywiście nieogrzewany, zimą ampułki gdzieś w kieszeni się trzymało. Potem wbiegło się jeszcze do domu, żeby zjeść jako takie śniadanie, $\mathrm{i}$ biec w drugą stronę miasta do szkoły na ósmą. Tam się właśnie tworzyło, tam się formowało powołanie kapłańskie ${ }^{22}$.

Kazimierz Świątek od 13 listopada 1929 roku był członkiem Sodalicji Mariańskiej, tę przynależność będzie cenił do końca życia. Był czcicielem Maryi i miłośnikiem różańca ${ }^{23}$. „Kardynał Kazimierz bardzo kochał modlitwę różańcową. (...) Po liturgii lubił zostać w kościele, aby pomodlić się w ciszy. Miło było na to patrzeć"24. W Baranowiczach

$20 \quad$ APSK, zapis rozmowy autora z ks. kard. K. Świątkiem, mps.

21 Por. M.A. Koprowski,Białoruś. Upartetrwanie polskości, Toruń 2006, s. 135-136.

APSK, zapis rozmowy autora z ks. kard. K. Świątkiem, która miała miejsce w Baranowiczach przed kościołem Podwyższenia Krzyża Świętego, mps. Zarejestrowany także przed kamerami telewizyjnymi. Por. film Pasterz - Kardynat Kazimierz Świątek, film dokumentalny, reż. S. M. Królak, P. Woldan, TVP SA 2002.

$23 \quad \mathrm{Na}$ podstawie legitymacji członkowskiej z 13 listopada 1929 roku, fotokopia w APSK, oraz rozmów z autora z ks. kard. K. Świątkiem, mps. Sodalicja Mariańskajest stowarzyszeniem religijno-społecznym zrzeszającym czcicieli Maryi. Charyzmat stowarzyszenia wyraża hasło Per Mariam ad maiorem Dei gloriam. Powstała w Rzymie w 1563 roku.

24 Świadectwo siostry Franciszki Bernadety Klim MSF, która od 1988 r. pracowała w Pińsku i w ostatnich miesiącach życia pomagała ks. kard. K. Świątkowi, 
na placu przed kościołem Podwyższenia Krzyża Świętego Kazimierz Świątek przez posługę biskupa pińskiego Zygmunta Łozińskiego otrzymał sakrament bierzmowania ${ }^{25}$.

\section{Powołanie}

Historia Kościoła
1933 roku Kazimierz Świątek zdał maturę w Gimnazjum im. Tadeusza Rejtana w Baranowiczach i złożył podanie o przyjęcie na polonistykę na Uniwersytecie Stefana Batorego w Wilnie. Na pożegnanie szkoły, już po maturze, absolwenci zorganizowali sobie ostatnią wycieczkę szkolną ${ }^{26}$ - do Pińska. I tam miało miejsce zdarzenie, które w decydujący sposób wpłynęło na życie Kazimierza Świątka. Tak je po latach wspominat:

Po zwiedzeniu katedry zeszliśmy do krypty, gdzie spoczywał biskup Łoziński. Wszyscy kładli rękę na metalowej trumnie, a ja miałem jakieś wewnętrzne opory i tego nie zrobiłem. Wyszliśmy z krypty. I wtedy pomyślałem, że muszę wrócić. Wróciłem i przy jego trumnie poprosiłem, żebym był prawdziwym sługą Chrystusa Pana. Nie miałem na uwadze, że kapłanem. Nawet na myśl mi to nie przyszło, miałem już załatwioną filologię na Uniwersytecie w Wilnie. To jedna prośba. A druga - żeby mama moja jak najdłużej żyła. A On dosłownie mnie wysłuchał. Zrobił ze mnie księdza, a mama przeszło 92 lata przeżyła ${ }^{27}$.

Wkrótce po wizycie w Pińsku Kazimierz Świątek wycofał dokumenty z Uniwersytetu i złożył je w Wyższym Seminarium Duchownym w Pińsku. Został przyjęty i jesienią 1933 roku rozpoczą studia. Należał do najlepszych studentów pod względem nauki i formacji osobistejej. Mimo upływu lat rodzina Świątków nie miała żadnych wiadomości o losach męża i ojca, który nie wrócił z wojny. W 1937 roku Kazimierz Świątek przejeżdżał przez Wilno i odnalazł swego Ojca.

tłumaczenie autora, http://catholic.by/2/libr/interview/109597-bernadeta-klim. html.
APSK, zapis rozmowy autora z JE ks. kard. K. Świątkiem, mps.

Ks. E. Borowski w Wyższe Seminarium..., op. cit. podaje, że były to rekolekcje sodalicyjne. W rozmowach z autorem niniejszego opracowania Ks. kardynał nigdy nie mówił o rekolekcjach.

APSK, zapis rozmowy autora z ks. kard. K. Świątkiem, mps.

W zachowanym Protokole Posiedzenia Rady Pedagogicznej WSD w Pińsku w dniu 2 grudnia 1936 roku zwierającym m.in. oceny alumnów pod węglem zdolności naukowych i duchowego ukształtowania mamy zapis „Kazimierz Świątek - bardzo dobry”. Za ks. E. Borowski, Wyższe Seminarium..., op. cit. s. 124. 
Ojciec został zmobilizowany i już nie wrócił. Nie odnaleźliśmy go. I ja go odnalazłem w Wilnie, na Rossach, jego mogiłę, jako legionisty. Zginął w zdobywaniu Wilna od bolszewików w podarunku dla Dziadka swego, dla Piłsudskiego. I tam kula sowiecka go trafiła. Ja w 1937 roku przejeżdżałem przez Wilno z obozu harcerskiego.... Zaszliśmy na Rossę... I wtedy nie wiem, co mnie tknęło... Oni śpiewają - ja ruszyłem między groby. I w przedostatnim szeregu, dziewiąta mogiła patrzę - Jan Świątek. Tam spotkałem swojego Ojca ${ }^{29}$.

3 kwietnia 1938 roku Kazimierz Świątek otrzymał święcenia subHistoria Kościoła diakonatu, a 18 września tegoż roku został diakonem ${ }^{30}$.

Prawdopodobnie niepewna sytuacja polityczna odczuwalna już wyraźnie na wiosnę 1939 roku i obawy przed wybuchem wojny spowodowały, że święcenia kapłańskie w Pińsku zostały przyspieszone. W Wielką Sobotę, 8 kwietnia 1939 roku, Kazimierz Świątek otrzymał w katedrze pińskiej święcenia kapłańskie ${ }^{31}$ z rąk biskupa ordynariusza Kazimierza Bukraby.

W Poniedziałek Wielkanocny, 10 kwietnia, o godzinie 11 odprawił w kościele Podwyższenia Krzyża Świętego w Baranowiczach uroczystą Mszę św. prymicyjną ${ }^{32}$.

$29 \quad$ APSK, zapis rozmowy autora z JE ks. kard. K. Świątkiem, która miała miejsce w Pińsku, mps. Zarejestrowany także przed kamerami telewizyjnymi. Por. film Pasterz-Kardynat Kazimierz Świątek, film dokumentalny, reż. S. M. Królak, P. Woldan, TVP SA 2002. Ksiądz kard. podaje, że był to rok 1937, ale wydaje się, że było to przejęzyczenie, jako że wówczas Kazimierz Świątek, był alumnem w seminarium w Pińsku. Jeśli rok jest właściwy, to zdarzenie mogło mieć miejsce w czasie wyjazdu alumnów na wypoczynek lub wycieczkę, lub też w czasie wakacji, gdy alumni mieli praktyki duszpasterskie w swoich parafiach.

Por. E. Borowski, Wyższe Seminarium..., op. cit. s. 145.

Droga do święceń nie była wolna od trudnych chwil. Ówczesny rektor pińskiego seminarium diecezjalnego ks. Aleksy Petrani (1900-1977) wnioskował nawet o usunięcie z seminarium K. Świątka. Chodziło o sprawę drobną: K. Świątek wraz z innymi alumnami płynęli łódką po Pinie. Kazimierz Świątek postanowił skorzystać z okazji i popływać nieco. Wymagało to oczywiście zdjęcia sutanny i rozebrania się do spodenek. Tak się też stało, młody alumn popływał sobie, ale całe zdarzenie widział z okna seminarium ks. rektor. To drobne zdarzenie, choć mogło mieć poważne konsekwencje, K. Świątek bardzo przeżył. Na podstawie informacji przekazanych autorowi przez ks. kard. K. Świątka, APSK.

APSK, na podstawie zapisu rozmowy autora z ks. kard. K. Świątkiem, mps, i kopi zaproszenia na Mszę św. prymicyjną. Ksiądz kardynał oprowadzał autora po Kościele Podwyższenia Krzyża Świętego w Baranowiczach i wspominał tę uroczystość. Wówczas cały wystrój kościoła był taki sam jak w 1939 roku (nie licząc nowego ołtarza zgodnie ze zmianami po Vaticanum Secundum). Ksiądz kardynał wspominał, że po Mszy św. udzielał błogosławieństwa prymicyjnego swej mamie, bratu Edwardowi, wujkowi Kazimierzowi, ciociom Urszuli 
Wówczas w kościele, a potem na przyjęciu w domu rodzinnym mógł spotkać się z całą rodziną. Kilka lat później zostanie od niej całkowicie odcięty na wiele lat.

\section{Doświadczenie krzyża}

\section{Pierwsza placówka duszpasterska}

\section{i pierwsza okupacja sowiecka}

21 kwietnia 1939 roku ks. Kazimierz Świątek objął stanowisko wikariusza w parafii Wniebowzięcia Najświętszej Maryi Panny w powiatowym mieście Prużana niedaleko Brześcia ${ }^{33}$. W kwietniu tegoż roku przeprowadzona został cicha mobilizacja, która objęła także dziekana i proboszcza prużańskiego, ks. Antoniego Rojko ${ }^{34}$, który został powołany na kapelana Wojska Polskiego. Ksiądz Kazimierz Świątek pozostał sam na dziekańskiej parafii i pełnił obowiązki proboszcza i dziekana, jako administrator parafii. Po agresji Niemiec na Polskę 1 września 1939 roku starał się nieść pomoc duchową parafianom, a także żołnierzom Wojska Polskiego i licznym cywilom uciekającym przed Niemcami na Wschód.

Od początku okupacji sowieckiej rozpoczęło się zwalczanie wiary, religii, Kościoła i duchowieństwa. Wykorzystywano wszystkie wypróbowane wcześniej w ZSRR metody. Równolegle prowadzono akcję deportacji i przemieszczania ludności polskiej, która stanowiła większość wiernych Kościoła katolickiego. Już 11 października 1939 Główna Komenda NKWD w Moskwie wydała rozkaz nr 001223, który stanowił formalną podstawę deportacji z nowych ziem w głąb ZSRS. Największe fale deportacji miały miejsce w lutym, kwietniu i czerwcu 1940 roku oraz w czerwcu 1941 roku $^{35}$. Precyzyjna liczba deportowanych, głównie na Sybir i do Kazachstanu, jest nadal przedmiotem badań, ale z Polesia i okolic Nowogródka wywieziono około 200 tysięcy osób ${ }^{36}$.

i Stanisławie; powiedział autorowi niniejszego artykułu, że wówczas rodzina i on płakali.

Por. dekret nominacyjny wystawiony przez ordynariusza pińskiego ks.K. Bukrabę 15.04.1939. Fotokopia w APSK.

Ksiądz A. Rojko urodzony w 1896 roku, 26.04. 1946 zagrożony aresztowaniem wyjechał do Polski, zm.5.03.1958, pochowany na cmentarzu parafialnym w Skrzatuszu, diec. koszalińsko-kołobrzeska, gdzie w latach 1946-1948 był proboszczem.

Zob. T. Walichnowski (red.), Deportacje i przemieszczenia ludności polskiej $w$ głą ZSRR 1939-1945, Warszawa 1989, s. 7n.

Ibidem, s. 16. 
W Prużanie sowieci pojawili się 21 września 1939 roku. Ksiądz Kazimierz Świątek niósł posługę duszpasterską i pomoc swoim parafianom i wszystkim jej potrzebującym - także tym działającym w konspiracji Rzeczypospolitej. Po latach tak ocenił swoje ówczesne zaangażowanie:

Nie wydaje mi się, żebym specjalnie w jakąś politykę się bawił, ale jeżeli chodzi o swoją postawę, to oczywiście nie ukrywałem, że jestem Polakiem i że tu dzieje się niesprawiedliwość, że tereny te zabierają, że zaczynają grabić i mordować. Niekoniecznie uważałem, że można to już zaliczyć do polityki, do działania przeciw ustrojowi. Oczywiście piętnowałem tam bezbożnictwo i ateizm ${ }^{37}$.

Taka postawa nie mogła pozostać niezauważona. W nocy 21 kwietnia 1941 roku ks. Kazimierz Świątek został aresztowany przez NKWD na plebanii w Prużanie i przewieziony do miejscowej siedziby tej formacji. Tego samego dnia został przetransportowany do Brześcia i umieszczony w separatce w dawnym więzieniu polskim wybudowanym nad Muchawcem przez wojewodę poleskiego Kostka Biernackiego, a po zajęciu Brześcia przez wojska sowieckie głównym miejscu kaźni w województwie poleskim ${ }^{38}$. Został oskarżony o przestępstwa z czterech artykułów sowieckiego kodeksu karnego - najlżejsze przestępstwo, propaganda antysowiecka, zagrożone było karą 10 lat łagrów, pozostałe - karą śmierci. Ksiądz Świątek przeszedł bardzo ciężkie śledztwo, o którym nie chciał mówić.

37 APSK, zapis rozmowy autora z ks. kard. K. Świątkiem, która miała miejsce w Pińsku, mps. Zarejestrowany także przed kamerami telewizyjnymi, por. film Pasterz - Kardynat Kazimierz Świątek, film dokumentalny, reż. S. M. Królak, P. Woldan, TVP SA 2002. R. Dzwonkowski SAC w Losy duchowieństwa polskiego represjonowanego $w$ ZSRS 19-39-1988, Lublin 2003, s. 584, podaje, że K. Świątek już w czasie okupacji sowieckiej należał do konspiracyjnej organizacji „Orzeł Biały”. W czasie wielu rozmów z autorem ks. kard. K. Swiątek wspominał, że niósł posługę duszpasterską osobom w konspiracji i żołnierzom Polski Podziemnej, ale nigdy nie stwierdził, że formalnie należał do „Orła Białego”, natomiast swoją w niej aktywność sytuował na czas okupacji niemieckiej.

APSK, na podstawie zapisu rozmowy autora z ks. kard. K. Świątkiem, mps. Zarówno budynek plebanii jak i ówczesnej siedziby NKWD przetrwały do upadku ZSRS. Autor niniejszego opracowania oglądał oba budynki. W byłej plebanii mieściły się mieszkania komunalne, a budynek NKWD, a następnie miejscowego KGB w latach dziewięćdziesiątych XX wieku kupił, bez wcześniejszej zgody ks. kard. Świątka, ówczesny proboszcz w Prużanie (noszącej obecnie nazwę Prużany) ks. E. Łojek CM z zamiarem urządzenia w budynku domu rekolekcyjnego. Rozpoczęła się renowacja obiektu, która jednak nie została doprowadzona do końca. W kwietniu 2009 roku autor niniejszej pracy był ostatni raz w Prużanie i stan obiektu nie uległ zmianie, remont nie został zakończony i obiekt nie był użytkowany. 
Nie będę mówił jak tam było ciężko, nie ciężko, ale jedno mogę powiedzieć, że - chyba na wzór biskupa Łozińskiego - a kiedy byłem tam przed swoimi śledczymi i prokuratorami, to powiedziałem sobie tak: zaciśnij zęby, co by oni z tobą nie robili, ale żeby nigdy łez w twoich oczach nie ujrzeli. I nie ujrzeli. Zęby nieraz tak zaciskałem, że krew mi aż z dziąseł szła, jak trzepali, ale nie zapłakałem, nigdy... ${ }^{39}$.

Kazimierz Świątek został skazany na śmierć i umieszczony w celi śmierci nr 140, gdzie oczekiwał na wykonanie wyroku. Każdej nocy o godzinie 23 NKWD zabierało z cel więźniów skazanych na śmierć i rozstrzeliwało.

22 czerwca 1941 roku o świcie niemieckie wojska przekroczyły „granicę przyjaźni” z ZSRS. Brześć został zajęty z marszu. W więzieniu nad Muchawcem siedziało wówczas około 7000 Polaków. Sowieci nie mieli czasu, by ewakuować więzienie lub wystrzelać więźniów, tak jak robili to $\mathrm{w}$ innych miastach, a czego wstrząsającym przykładem może być ewakuacja obozu w Berezweczu ${ }^{40}$. Oto relacja ks. Kazimierza Świątka z tego dnia:

Nie ruszyli nikogo w więzieniu, tak byli przerażeni. Porzucili wszystko i pouciekali. Pamiętam, że jak siedziałem w tej celi śmierci, to tam takie malutkie okienko było, od bombardowania szybka wyleciała i dym od niemieckiego bombardowania wlatywał. I ja tak stałem, i patrzyłem: o tam - to wolność. A z tyłu za mną w drzwiach judasz raz po raz się otwierał i ja sobie myślałem: zaraz strzeli do mnie i koniec... Więc ja stałem tyłem do tego judasza i patrzyłem na tę wolność... Ale strzał nie padł. Ucichło wszystko, a gdzieś godzinę później słyszę szum jakiś, trzask jakiś na korytarzu... To miejscowa ludność zaczęła rozbijać więzienie, wreszcie dotarła i do mojej celi, ludzie wyrąbali te żelazne drzwi i tak ja wyszedłem na wolnośśc ${ }^{41}$.

39 APSK, zapis rozmowy autora z ks. kard. K. Świątkiem, mps. Autor wielokrotnie rozmawiał z ks. kard. K. Świątkiem na temat śledztwa i pobytu w łagrach, ale zawsze były to krótkie wypowiedzi, gdyż ks. Kardynał uważał, że „nie warto wspominać tych strasznych czasów".

$40 \quad$ Por. R. Dzwonkowski SAC, Z historii Kościoła katolickiego w ZSRS 1917-1991, Ząbki 2005, s. 207.

41 APSK, zapis rozmowy autora z ks. kard. K. Świątkiem, mps. Fakt uwolnienia potwierdził 26 czerwca 1941 roku proboszcz i dziekan brzeski. Zaświadczenie przez niego wystawione tego dnia w Brześciu znajduje się w archiwum prywatnym ks. kard. K. Świątka, kopia w APSK. 


\section{Okupacja niemiecka}

Po uwolnieniu ks. Kazimierz Świątek skierował się na Wschód. Znał niemiecki, w razie potrzeby wyjaśniał niemieckim wojskowym, że wyszedł z sowieckiego więzienia i wraca do parafii. Do zajętej już przez Niemców Prużany dotarł 30 czerwca $^{42}$.

Przychodzę do plebani, na drzwiach plebani kartka wisi: zajęte przez gestapo. Otwieram drzwi, pierwsza była kancelaria, na lewo gabinet, otwieram te drzwi - moje biurko, właściwie proboszcza, ale ja je zajmowałem, a przy nim siedzi major. Od razu trafiłem z deszczu pod rynnę ${ }^{43}$.

Ksiądz Kazimierz Świątek został natychmiast przesłuchany, ale zwolniony i przez prawie dwa lata okupacji niemieckiej prowadził w Prużanie pracę duszpasterską, kierował parafią, pełnił obowiązki dziekana i aktywnie wspierał posługą duszpasterską żołnierzy Polski Podziemnej ${ }^{44}$. Wzywany co jakiś czas na gestapo argumentował, że wykonując pracę duszpasterską, potępiając bezbożnictwo i ateizm sprzeciwia się systemowi sowieckiemu. Było to skuteczne, a może po prostu Niemcy nie mieli jeszcze wystarczających dowodów przeciwko niemu. W lipcu 1944 roku ks. Kazimierz Świątek został ostrzeżony przez swoją parafiankę, która pracowała jako gospodyni u owego majora gestapowca, który zamieszkał na plebanii, że grozi mu śmierć.

Przybiegła do mnie około północy: „Proszę księdza trzeba uciekać. Major wrócił bardzo pijany i mówił do siebie i ja podsłuchałam, że jest decyzja, aby rozstrzelać księdza. Mówił, że wiedzą o organizacji AK «Orzeł Biały», do której ksiądz należy”. (...) Następnego dnia patrzę na ulicy przed furtką, naprzeciw drzwi wejściowych do plebanii stoi jego wóz, a on przy nim. Podszedłem a on mówi po niemiecku do mnie: „Księże proboszczu, otrzymałem rozkaz wyjazdu dalej na Wschód. I dlatego też, siedział już w samochodzie, dziękuję panu za mieszkanie, za wszystko. Przyjdzie tu mój następca”. Jeszcze popatrzył tak na mnie i dodał: „To czego ja nie zrobiłem, niech on zrobi. Auf wiedersehen”. I odjechał" ${ }^{45}$.

${ }_{42} \quad$ Por. K. Świątek ks. kard., Wspomnienia. 70. Rocznica święceń kapłańskich 8.IV. 1939 r., APKS, kopia w APSK, mps, s. 2. Por. przyp. 35.

APSK, zapis rozmowy autora z ks. kard. K. Świątkiem, mps. 


\section{Druga okupacja sowiecka}

Historia Kościoła

Kilka dni później, 17 lipca 1944 roku o 12 w południe Prużanę zajęły wojska sowieckie ${ }^{46}$. Jeszcze tego samego dnia SMIERSZ ${ }^{47}$, sowiecki kontrwywiad, zapukał do drzwi mieszkania ks. Kazimierza Świątka.

O 12 zajęli to miasto, a o 3 nad ranem do mego pokoju wszedł sowiecki kontrwywiad. I mówią tak: To wy nie uciekliście razem z nazistami? Nie. To dobrze, a właściwie to wszystko jedno, bo my pana i pod ziemią byśmy znaleźli. I zabrali mnie do siebie ${ }^{48}$.

Po przesłuchaniu ks. Kazimierz Świątek został zwolniony i wrócił do swoich obowiązków. W ciągu kolejnych najbliższych miesięcy był inwigilowany i nękany, ale mógł pracować.

27 lipca 1944 roku PKWN podpisał umowę z ZSRS o przebiegu granicy polsko-sowieckiej na podstawie tzw. linii Curzona, a kilka dni później, 1 sierpnia, ów komitet został przez Kreml uznany za rząd polski. Ksiądz Kazimierz Świątek, jak miliony innych obywateli polskich mieszkających we wschodnich województwach, był już formalnie obywatelem sowieckim. Tym niemniej tak on, jak i większość innych kapłanów odmawiali uznania tego obywatelstwa i uważali się za obywateli polskich. 9 września 1944 roku w Lublinie podpisane zostało polsko-białoruskie porozumienie o przesiedleniu ludności. Przesiedlenia miały być dobrowolne. W praktyce było inaczej. Jesień i zima była okresem wielkiego napięcia dla mieszkańców ze wzglądu na ciągłe szykany ze strony władz administracyjnych i policyjno-wojskowych wprowadzających ustrój sowiecki, konieczność podejmowania decyzji o opuszczeniu ziemi ojczystej, nie mając przy tym pewności otrzymania zgody na wyjazd. Szczególnie bowiem z terenów Białorusi władze sowieckie utrudniały wyjazd do Polski, zwłaszcza mieszkańcom wsi. Wielką duchową pomoc nieśli im w tym okresie księża katoliccy. Niewolni wszakże sami od dylematów związanych z decyzjami o wyjeździe bądź pozostaniu. Ksiądz Kazimierz Świątek nie miał zamiaru wyjeżdżać i nie uważał się za obywatela sowieckiego, ale formalnej decyzji nie podjął i podejmować nie musiał.

46 Informacja własna autora na podstawie oficjalnej kroniki miasta Prużany, obwodu brzeskiego, Republiki Białoruś.

47 SMIERSZ, powszechna nazwa kontrwywiadu wojskowego ZSRS w czasie II wojny światowej, od słów smiert' szpionam, śmierć szpiegom, formalnie nazwa wprowadzona uchwałą Rady Komisarzy Ludowych ZSRS z 19 czerwca 1943, która powoływała Gławnoje Uprawlenie Kontrrazwiedki SMIERSZ Narodnowo Komissariata Oborony SSSR (Główny Zarząd Kontrwywiadu SMIERSZ Ludowego Komisariatu Obrony ZSRS).

48 APSK, zapis rozmowy autora z ks. kard. K. Świątkiem, mps. 
17 grudnia 1944 roku został aresztowany przez NKWD na plebani w Prużanie i po przesłuchaniu w siedzibie miejscowego NKWD wywieziony do wewnętrznego więzienia NKWD w centrum Mińska ${ }^{49}$. Przez siedem miesięcy poddawany był tam brutalnemu śledztwu. Podobnie jak trzy lata wcześniej w Brześciu, tak i teraz zachował postawę niezłomną i pełną godności.

Po kilku miesiącach, pewnej nocy, gdzieś koło 12, pułkownik, który prowadził badania wchodzi i mówi: wstawaj, idziemy. Zaprowadził mnie przed jakiś gabinet, wepchnął mnie do środku. Za biurkiem stał w mundurze galowym generał NKWD z takimi charakterystycznymi lampasami. I ten generał zaczyna mi banialuki opowiadać. I zaczynam rozumieć, że on sonduje mnie, czy nie da się mnie zwerbować do ich pracy. (...) W pewnym momencie mówi: „Słuchaj, u Rosjan jest takie powiedzonko: lepiej być żywą wroną niż martwym orłem”. A ja wtedy zdobyłem się na taką energię, wyprężyłem się, na baczność stanąłem i mówię: obywatelu generale, z jaką dumą mogę panu powiedzieć, że język polski nie zna takiego przysłowia. Jaka była jego reakcja? Na biurku miał taką masywną popielniczkę czy coś podobnego. Roztrzaskałby mnie nią na miejscu, gdybym ja głowy nie odsunął. Rozbiła się o ścianę, rozleciała się na kawałki. A on wrzasnął do tego pułkownika śledczego: „Zabierz tę polską swołocz, bo zabiję!”50.

W Mińsku ks. Kazimierz Świątek był także więziony w istniejącym do dzisiaj więzieniu przy ulicy Wołodarskiego. 21 lipca 1945 roku został skazany na 10 lat łagrów o zaostrzonym reżimie i 5 lat pozbawienia praw obywatelskich ${ }^{51}$. Od aresztowania ks. Kazimierz Świątek był

Więzienie to znajdowało się w liczących kilka pięter podziemiach głównej siedziby NKWD w Mińsku.

APSK, zapis rozmowy autora z ks. kard. K. Świątkiem, mps.

Data wyroku i nazwa sądu, który go wydał budzi pewne kontrowersje. W literaturze przyjmuje się datę 25 lipca i cywilny Sąd Obwodowy Białorusko-Litewski, który skazał K. Świątka z art. 63 "a" i art. 78 KK BSRS (por. R. Dzwonkowski, Leksykon duchowieństwa..., op. cit., s. 584). Jednakże w dokumentach, z którymi zapoznał się autor niniejszej rozprawy, wystawianych przez władze sowieckie figuruje data 21 lipca 1945, por. APKS, Sprawka nr M0034819 wystawiona 16.06.1954 r. przez komendanta łagru w Incie przy zwalaniu K. Świątka, kopia w APSK. W dokumencie tym podane jest także, że wyrok na ks. K. Świątka wydał sąd wojskowy, a nie cywilny. O tym, że formalnie wyrok wydał sąd wojskowy świadczy także fakt, że prośbę o rehabilitację złożoną przez ks. K. Świątka w 1956 roku (odrzuconą) rozpatrywał trybunał wojskowy. Także ks. kard. K. Świątek w rozmowie z autorem niniejszego artykułu podał datę 21 lipca 1945 roku. Ta sama data znajduje się także w cytowanym dokumencie Wspomnienia. 70. Rocznica święceń kapłańskich... autorstwa ks. kard. K. Świątka. Być może trójka NKWD tylko oznajmiła wyrok skazanemu, ale formalnie wyrok wydał sąd wojskowy. 
izolowany i ani rodzina, ani parafianie nie mieli żadnej informacji o jego losach ${ }^{52}$. Podkreślić jednak trzeba, że mimo panującego terroru parafianie z Prużany nie zapomnieli o swoim proboszczu. Zachowały się prośby pani Jeleny Sadowskiej z Prużany skierowane do naczelnika więzienia w Mińsku, w których prosi ona o zgodę na przekazanie więźniowi Kazimierzowi Świątkowi paczek zawierających bieliznę i nieco żywności. Ta prośba, jak i inne, w tym matki, pozostały bez odpowiedzi. Władze sowieckie przyjęły natomiast pieniądze, które pani Sadowska przekazała dla ks. Kazimierza Świątka ${ }^{53}$.

\section{Więzień łagrów}

Po wyroku ks. Kazimierz Świątek został przewieziony do więzienia przesyłowego (rozdzielczego) w Orszy, gdzie zapadł na dyzenterię. W sali, na betonowej podłodze więzienia leżało około 200 więźniów, wśród nich półprzytomny Kazimierz Świątek. Pomocy lekarskiej w zasadzie nie było żadnej. Któregoś dnia pojawił się lekarz, który zapytał, czy ktoś nie ma prześcieradła. Kazimierz Świątek podniósł rękę do góry, bo miał prześcieradło, które w czasie aresztowania w Prużanie włożyła mu do walizki gospodyni, a którego nie chciał zabrać i ustąpił, gdy enkawudzista widząc jego opór powiedział: , przyda się”. To prześcieradło uratowało mu życie, gdyż lekarz zabrał go do sali chorych. Inaczej by nie przeżył. Dla ks. Kazimierza Świątka był to dowód Bożej dobroci. „Nie uznajemy cudów, uważamy wszystko za normalny bieg życia"54.

Z Orszy więzień Kazimierz Świątek został wysłany w okolice, które już kiedyś we wczesnym dzieciństwie poznawał - w rejon Krasnojarska, do Mariinskich Eagierej ${ }^{55}$, gdzie przez dwa lata pracował przy wyrębie tajgi.

52 Matka Kazimierza Świątka wyjechała do Polski w 1945 roku nie otrzymawszy żadnych informacji o losach aresztowanego syna. Ksiądz Świątek odnalazł ją w 1957 roku w Opolu.

APKS, kopia w APSK. Prośby pisane były odręcznie, nie zawierają daty. Autorka prosiła o możliwość dostarczenia artykułów spisanych w jednej prośbie w dwudziestu pozycjach, w drugiej w ośmiu. Są to m.in. koszule, spodnie, buty, ręcznik, mydło, słonina, suchary, ser i konserwy. Pani Sadowska mieszkała wówczas w Prużanie przy ulicy Sowieckiej 69. Kwitancja nr 43/5 z 4.02.1946 opiewa na kwotę pięciuset rubli wpłaconych dla więźnia K. Świątka.

APSK, zapis rozmowy autora z ks. kard. K. Świątkiem, mps. 
Było to w tych samych stronach, gdzie ja byłem w dzieciństwie. Bo pamiętałem, że latem była taka sama przyroda, takie same krzewy, kwiaty. Ale teraz straszne to były warunki, bo rąbaliśmy ręcznie pnie drzew, które trzech mężczyzn ledwie mogło objąć. Zimą szliśmy siedem kilometrów pieszo przez pięciometrowe zaspy. Jeśli nie wykonało się normy, to wieczorem dawali 250 gramów chleba i bałangę - zupę z kotła gotowaną na paru liściach kapusty i kilku zgniłych kartoflach. Jak ktoś umierał, to rozbierali do naga i wyrzucali w zaspy. Potem ciałami zajmowały się lisy i wilki. Według regulaminu, jeśli było poniżej minus trzydzieści siedem i pół stopnia, to nie wychodziło się do pracy. Ale naczelnik uważał, że do prac awaryjnych można wyjść i przy minus pięćdziesięciu. Ludzie padali jak muchy ${ }^{56}$.

Ale i tam ks. Kazimierz Świątek był ukrytym duszpasterzem dla nielicznych więźniów.

W pierwszych latach w obozie panował terror. Ja nie ukrywałem, że jestem księdzem, ale o pracy duszpasterskiej nie mogło być mowy. Było to surowo zabronione, a kryminaliści o wszystkim donosili władzom obozu. Więźniowie bali się kontaktów ze mną. Ale jednak kilku wyspowiadałem ${ }^{57}$.

Może właśnie dlatego, że podejrzewano go o pracę duszpasterską zmieniono mu miejsce pobytu.

3 września 1947 roku ewakuowano go z łagru w tajdze do łagru w okolicach Workuty. Warunki były tu jeszcze cięższe niż we wschodniej Syberii.

Trzy tygodnie później, 24 grudnia, ks. Kazimierz Świątek urządził w jednym $\mathrm{z}$ baraków Wigilię.

Zgromadziłem Polaków. Lgnęli do mnie, kiedy dowiedzieli się, że jestem księdzem. Postanowiliśmy, że kto co może, to przyniesie. Pamiętam, że trzy dni chleba nie jadłem, żeby potem pod dostatkiem było na Wigilię. Kilku więźniów było z Ukrainy; oni dostali jakieś paczki żywnościowe i w jednej z nich znalazły się opłatki. Wigilia mogła być z opłatkiem. Poprosiliśmy innych więźniów, żeby wyszli z jednej izby. Zrobiliśmy stoły. Co kto miał, postawiliśmy. I siłą faktu trzeba było mnie przemawiać. Trzymałem w ręku ten opłatek, myślałem - co powiedzieć, nastrój oczywiście taki...no, wigilijny, w tych warunkach. I w pewnym momencie drzwi się nagle otwierają i wchodzi naczelnik reżimu ${ }^{58}$

\footnotetext{
$56 \quad$ APSK, zapis rozmowy autora z ks. kard. K. Świątkiem, mps.

57 APSK, zapis rozmowy autora z ks. kard. K. Świątkiem, mps. Por. K. Renik, Podpolnicy, Warszawa 1991, s. 209. 
Historia Kościoła

z naganem w ręku. I za nim żołnierz z karabinem i bagnetem. Ktoś widocznie doniósł, że Polacy gdzieś tam się zbierają. I od razu do mnie z tym wyciągniętym naganem, wszyscy wstali... „Co tu robicie?” - pyta. Ja wtedy po rosyjsku jeszcze nie za dobrze mówiłem, ale jak umiałem, to tłumaczyłem naczelnikowi o naszym zwyczaju, o tym, czym jest dla nas Wigilia. I pod koniec tak mówię: „Proszę pana, właściwie nie mówiłem pan - mówiłem «obywatelu naczelniku», u nas, u Polaków, jest jeszcze taki zwyczaj, że jeżeli na Wigilię ktoś przyjdzie, to go przyjmujemy; nawet jeżeli jest to wróg - to też go przyjmujemy, dzielimy się opłatkiem i prosimy by zasiadł do stołu. Dlatego ja, niech pan mi pozwoli", podchodzę bliżej, tak na trzy metry, bo bliżej nie można, bo jak podeszło się mniej niż trzy metry, to strzelali bez ostrzeżenia, bo uważali, że może chce się napaść. Podchodzę, wyciągam ten opłatek i mówię: „proszę bardzo, podzielmy się opłatkiem”. On stoi z wyciągniętym w moim kierunku naganem, a naprzeciw stoję ja z wyciągniętą ręką z opłatkiem. Stałem patrzyłem na niego i myślałem sobie: Ja ręki pierwszy nie opuszczę - będę trzymał opłatek. I myślałem: Ciekawe kto wytrzyma? Czyja ręka pierwsza opadnie? W pewnym momencie jego ręka opada, do kabury wkłada ten rewolwer, do żołnierza: „W tył zwrot, odmaszerować” - wygnał go. A do mnie mówi: „Prodałżajtie swoju biesiedu!" Proszę kontynuujcie swoją kolację, swoje spotkanie! I poszedł. Jak on wychodził z baraku zaintonowałem Wśród nocnej ciszy. To była najpiękniejsza Wigilia w moim życiu. Najpiękniejsza ${ }^{59}$.

Wigilia przebiegła już do końca bez żadnych zakłóceń, radość więźniów była ogromna. Ale już rano okazało się, że Kazimierz Świątek musi zapłacić za niesubordynację i zorganizowanie Wigilii.

O godzinie 6 rano pobudka i ruszamy do pracy. Przy wyjściu z obozu we wrotach mnie zatrzymali i od razu, z miejsca, wsadzili do pociągu. Wywieźli mnie z Workuty w tundrę, gdzie nie było ani obozów, ani domów, nie było nic, dosłownie nic. Tylko śnieg. I tam właśnie takich wyrzutków społeczeństwa jak ja wywalali. Ja nie wiem, jak to się tam przeżyło... [JE ks. kard. K. Świątek ze wzruszenia nie mógł przez chwilę mówić - przyp. autora]. Tak... Jałowce jakieś były, wodę trzeba było wyciskać z mchu, ognisko można było zapalić, dali nam jakieś zapałki. Pod gołym niebem. Później wybudowaliśmy pierwszy jakiś barak, żeby był dach nad głową. Byłem tam 7 lat. Kiedy stamtąd wyjeżdżałem stało już powiatowe miasto - Inta ${ }^{60}$. My łagiernicy je zbudowaliśmy. Pracowałem jako budowniczy, nauczyłem się i budowałem domy, że hej!61.

59 APSK, zapis rozmowy autora z ks. kard. K. Świątkiem, mps.

60 Inta, miasto w północno-wschodniej części Autonomicznej Republiki Komi w Rosji, ok. 1600 km od Moskwy, status miasta otrzymała w 1954 roku.

61 APSK, zapis rozmowy autora z ks. kard.K. Świątkiem. Ksiądz Kardynał zawsze był niezwykle oszczędny w opisywaniu przeżyć obozowych, niechętnie o nich mówił. Autor wie jednak, że ks. Świątek przewieziony do tundry na przełomie 
Łagiernicy budowali również linię kolejową nr 303 z Inty w kierunku Oceanu Lodowatego. I nawet tam Polacy starali się zaznaczyć swój patriotyzm.

Budowaliśmy tę linię 303 i w pewnym miejscu miała być stacja. Trzeba ją było jakoś nazwać. Tak się złożyło, że wtedy razem pracowało nas chyba czterech Polaków. Zaproponowaliśmy nazwę Wiślana, na pamiątkę Wisły. NKWD się nie zgodziło, więc zmieniliśmy na Wieślana, wtedy machnęli ręką i na tabliczce wypisaliśmy czarną farbą Wieślana. I tak powstała nowa stacja sowieckich kolei. Nie wiem, czy dziś jeszcze jest, ale przez kilka lat istniała ${ }^{62}$.

Od początku swego pobytu w łagrach ks. Kazimierz Świątek starał się, na ile to było tylko możliwe, nieść pomoc i opiekę duchową Polakom i innym więźniom, którzy się do niego zwracali. Najważniejszą z możliwych form pomocy - był sakrament spowiedzi, który sprawował. Niestety sam był tej możliwości pozbawiony.

W pierwszym roku pobytu w łagrach spotkałem jednego biskupa unickiego i u niego się wyspowiadałem. Potem dziewięć lat przeżyłem bez spowiedzi - nie miałem możliwości, nie spotkałem żadnego księdza. To było najcięższe, najtrudniejsze ${ }^{63}$.

Po wywiezieniu do tundry dodatkową szykaną dla ks. Kazimierza Świątka było całkowite odizolowanie go od Polaków. Dopiero po kilku latach spotkał ich w łagrze. W tym samym mniej więcej czasie pojawiły się możliwości odprawiania Mszy św.

Dopiero gdzieś w siódmym, ósmym roku, po kryjomu zacząłem odprawiać Mszę świętą. Niektórzy otrzymywali paczki. Pomyślałem, żeby rodzynki przysłali. Otrzymywali to niby na Boże Narodzenie. Opłatki i rodzynki. Do rodzynek troszeczkę wody dolewałem i było wino, czyste wino. Teksty Mszy świętej króciutkie umiałem na pamięć i po kryjomu zacząłem, na tych pryczach, odprawiać Mszę świętą. I miałem kielich, taki mały kubeczek bez rączki, który kupiłem u jednego więźnia za porcję dzienną chleba. Musiałem mieć puszkę, aby przechowywać konsekrowane komunikanty, bo nosiłem je do więźniów. Puste pudełko od zapałek - to była moja puszka. Czasami mogłem odprawiać Mszę świętą z udziałem współwięźniów. Pamiętam, że któregoś roku Rezurekcję

roku 1947/1948 w okolice dzisiejszej Inty, gdzie jeszcze nie było nawet obozu, a jedynie tworzony łagier punkt znalazł się w skrajnie trudnych warunkach. Więźniowie zimą nocowali pod gołym niebem, bez namiotów, jedynie zagrzebani w śniegu, z głodowymi racjami żywieniowymi, aby przeżyć zdani byli wyłącznie na własną zaradność, pracując jednocześnie przy tworzeniu obozu. Por. R. Dzwonkowski SAC, Leksykon duchowieństwa..., op. cit. s. 584. 
Historia Kościoła

z udziałem współwięźniów odprawiłem w obozowej pralni, w kłębach pary wodnej, obok moczących się w kadziach ubrań więźniów. Ołtarzem były jakieś skrzynki ${ }^{64}$.

Pod opieką duszpasterską miał głównie Polaków, Litwinów i Łotyszy. Ksiądz Kazimierz Świątek przebywał w łagrach w okolicach Inty do końca wyroku.

W [tysiąc dziewięćset] pięćdziesiątym czwartym [roku], w czerwcu, wezwano mnie do biura poza obozem. Siedział tam major KGB, naczelnik obozu. Kazał mi stać pod ścianą, a sam siedział przy biurku i miał przed sobą stos teczek. Zaczął je przeglądać. Były to raporty, meldunki, uwagi na mój temat zbierane przez całe dziesięć lat. I kiedy on zakończył to przeglądać, spojrzał na mnie, i zwrócił się do mnie, oczywiście na „ty”: „Powiedz, jak ty to wszystko przeszedłeś i zostałeś żywy?”. No, co ja mu miałem odpowiedzieć? Odpowiedziałem: „Proszę pana, może dla pana to będzie niezrozumiałe, jak sądzę, ale przy życiu mnie zachował Pan Bóg, w którego ja mocno wierzę”. On tak spojrzał i mówi: „A czy jest ten Bóg?". Nie powiedział, że nie ma Boga. I mi przypomniała się od razu ta scena z Panem Jezusem i Piłatem, jak Pan Jezus powiedział: „prawda”, a on: co to jest prawda? Teraz major NKWD zapytał: - A czy jest ten Bóg? I zamilkł. Zastanawiał się. Ja patrzyłem na niego... Modlić się trzeba w takich momentach...65. Tak było jak na rozstrzelanie mnie prowadzili. Wtedy człowiek już tępieje i nie ma jakiejś głębszej refleksji, nie myśli o modlitwie subtelnej, przemyślanej, ale ma w sercu i na myśli normalny, zwyczajny „Ojcze nasz” i „Zdrowaśka”. Kończy się „Zdrowaś” i zaczyna „Ojcze nasz”. Akt żalu króciutki za wszystkie swoje grzechy i później „Ojcze nasz”, „Zdrowaś Mario”. Ja tak odmawiam jeden raz „Ojcze nasz”, drugi raz „Ojcze nasz”, a on tak ciągle myśli, zastanawia się... Wreszcie tak spojrzał na mnie, pierwszy raz w ciągu dziesięciu lat kagiebowiec spojrzał na mnie po ludzku. Nawet z pewnym uśmiechem. I powiedział: „No cztoże, wy... swobodny!” No cóż, pan jest wolny. Pierwszy raz na „pan”. Wyszedłem od niego bez konwoju ${ }^{66}$.

Wiele lat później, wspominając ostatni okres uwięzienia powiedział, Janowi Pawłowi II, że był wówczas już „u kresu wytrzymałości”67.

64 Ibidem.

65 Wzruszenie na wspomnienie tego wydarzenia i opis ówczesnego stanu ducha więźnia wraz z modlitwą wynika z tego, że w systemie łagrów sowieckich komendant obozu o zaostrzonym reżimie był panem życia i śmierci, mógł więźnia zwolnić po zakończeniu wyroku lub przedłużyć pobyt praktycznie bezterminowo, co najczęściej oznaczało wyrok śmierci.

APSK, zapis rozmowy autora z ks. kard. K. Świątkiem, mps.

APSK, świadectwo ks. kard. Stanisława Dziwisza, zapis rozmowy autora z ks. kard. Stanisławem Dziwiszem, mps. 
Świadectwo wiary w Boga wobec funkcjonariusza zbrodniczej formacji sowieckiego systemu przez więźnia, który skazany został na śmierć, który cierpiał w nieludzkich warunkach właśnie dlatego, że nie sprzeniewierzył się Chrystusowemu kapłaństwu dane w momencie, gdy zapadała decyzja o jego ostatecznym losie, świadczy o tym, że ks. Kazimierz Świątek wyznawał wiarę w Boga w stopniu heroicznym.

Było to 16 czerwca 1954 roku. Ksiądz Kazimierz Świątek był wolny, ale nie do końca. Musiał podać miejsce, gdzie zamierza pojechać. Powiedział, że do Polski. Usłyszał, aby nie żartował, bo pytanie jest poważne i że nie może jechać ani do Moskwy, ani do żadnego miasta wojewódzkiego (obwodowego) w ZSRS. Powiedział, aby w dokumencie wpisali, że kierują go do Połonnego ${ }^{68}$ na Ukrainie, bo więźniowie opowiadali, że przed nim był w Workucie kapłan, który został zwolniony i wyjechał do tej miejscowości. „Na co oni pytają: «A dlaczego tam chcecie jechać?» Na co ja: «Mnie wszystko jedno. Piszcie Workuta lub Kołyma». I wpisali Połonne"69. Dziesięć lat katorżniczej pracy wyceniono na 636 rubli, które wręczono zwalnianemu więźniowi ${ }^{70}$.

\section{Proboszcz w katedrze pińskiej}

Ksiądz Kazimierz Świątek pojechał na Ukrainę i w Połonnem zgłosił się do owego księdza, który sprawował duszpasterstwo w miejscowym kościele. Ale wkrótce okazało się, że przyjazd tam nie był najlepszym pomysłem.

On trzymał mnie w ukryciu. Bał się. W końcu mówi: „Wiesz co, na Ukrainie jest mało księży, ale ty nie jesteś z Ukrainy, tylko z pińskiej diecezji. To dobieraj się do Pińska. Nielegalnie, bo masz obowiązek być tu, ale jakoś się dobierzesz”. Odpowiedziałem: „Pewnie. Jakoś dotrę”. I ruszyłem. Trochę pociągiem, trochę autobusem, trochę samochodem, trochę pieszo, ale szczęśliwie dotarłem do Pińska. Był to lipiec 1954 roku $^{71}$.

68 Połonne, miasto rejonowe na Wołyniu, niegdyś w dekanacie zasławskim, obecnie siedziba dekanatu w diecezji Kamieniecko-Podolskiej na Ukrainie, świątynią miasta jest pobernardyński barokowy kościół św. Anny. Było to centrum życia polskiego na Ukrainie, także w ZSRS, obecnie miejscowi Polacy czują się tam dyskryminowani ze względu na rosnący nacjonalizm ukraiński. Por. R. Dzwonkowski, Leksykon duchowieństwa..., op. cit., s. 159-162.

69 APSK, zapis rozmowy autora z ks. kard. K. Świątkiem, mps. Por. Sprawka nr M0034819, op. cit.

70 Por. Sprawka nr M0034819, op. cit.

71 APSK, zapis rozmowy autora z ks. kard. K. Świątkiem, mps. Proboszczem w Połonnem w latach 1947-1955 był ks. Antoni Chomicki (1909-1993), żołnierz AK, w latach 1995-1958 proboszcz w Szarogrodzie, a następnie aż do śmierci w Murafie. Wybitnie zasłużony kapłan w pracy duszpasterskiej na Ukrainie, 
Historia Kościoła

Pierwsze kroki ks. Kazimierz Świątek skierował do katedry, która nie została zamknięta ${ }^{72}$. Była to zasługa miejscowych wiernych, głównie kobiet, które nie raz tworzyły żywy mur i nie pozwoliły jej zamknąć.

Kiedy zaszedłem do katedry w niedzielę, w ławkach było... 20 może 25 osób. Staruszki. (...) Na ołtarzu leży ornat, stoi kielich... I zaczyna się jakby Msza święta, po polsku. Później wstaje jedna niewiasta, wszyscy też wstają, a ona czyta: - Ewangelia święta przeznaczona na taką i taką niedzielę. I ja psychicznie nie wytrzymałem i zacząłem beczeć. Bo tak myślę: Boże, do jakich czasów dożyliśmy, że Ewangelię czyta niewiasta, a ksiądz stoi pod filarem i płacze. Naprawdę taka scena była. I kiedy się skończyła ta Msza, jakoby, przychodzę do zakrystii, no, kto mnie tam mógł poznać, i mówię: „A co u was księdza nie ma? - No nie ma. - A dawno nie ma? - Już sześć lat nie ma. - A chcielibyście mieć księdza? - O, jak byśmy chcieli! - Ja jestem księdzem”. Popatrzyli na mnie dziwnie. Ślady więziennej przeszłości były nadto wyraźne. Do księdza na pewno nie byłem podobny. „Udowodnię wam, że jestem księdzem. A tymczasem zapiszcie moje imię, nazwisko i składajcie podanie, że chcecie, bym był waszym proboszczem" "73.

Pięć miesięcy trwały zabiegi o uzyskanie zgody na pracę w pińskiej parafii katedralnej, tzw. sprawki dla ks. Kazimierza Świątka. W tym czasie w diecezji było zaledwie dwóch księży. „W Baranowiczach był mój kolega kursowy Stanisław Rogowski, a w Czernawczycach - Antoni Grzybowski, 4 lata starszy"74.

Dzisiaj już wiadomo, że te pięć miesięcy było ostateczną próbą, jakiej władze sowieckie postanowiły poddać Kazimierza Świątka. KGB ${ }^{75}$ w Pińsku dostało w 1954 roku z Mińska polecenie, aby za wszelką cenę skłonić „byłego więźnia Kazimierza Świątka”, by przestał pracować jako ksiądz. „Obiecujcie jemu wszystko, co tylko możecie. Jeśli jednak

gdzie przez wiele lat był jedynym kapłanem katolickim w centralnej części Ukrainy, łącznie z Kijowem.

Katedrę pińską wojska sowieckie chciały zniszczyć już we wrześniu 1939 r. Ocalała dzięki osobistej interwencji biskupa pomocniczego pińskiego ks. Karola Niemiry, który zdołał przekonać sowieckiego dowódcę, że z katedry nikt nie strzelał do wkraczających wojsk sowieckich, na podstawie relacji ks. kard. K. Świątka; por. reportaż telewizyjny Kapłan z gułagu, cz.2, reż. S. Auguścik, Telewizja Polska 1990.

APSK, zapis rozmowy autora z ks. kard. K. Świątkiem, mps.

Ks. Antoni Grzybowski ( - 1988), kapłan diecezji pińskiej, pracował w Czernawczycach i Peliszczach. APSK, zapis rozmowy autora z JE ks. kard.K. Świątkiem, mps.

KGB, Komitiet Gosudarstwiennoj Biezopastnosti, powstał w 1954 roku i przejął zadania zlikwidowanego MGB, Ministetierstwa GosudarstwiennojBiezopastnosti ZSRS, które w 1946 roku przyjęło zadania zlikwidowanego wówczas NKWD. 
wszystkie próby zawiodą, to zarejestrujcie jego jako księdza w Pińsku”76. „I rzeczywiście obiecywali: i dyrektora i naczelnika i pieniążki. A ja ciągle mówię: nie, nie, nie. Wytrzymałem i zarejestrowali" 77.

Stwierdzenie „wytrzymałem” odnosi się do pięciomiesięcznego nękania w Pińsku przez KGB formalnie wolnego ks. Kazimierza Świątka. Był on wówczas wielokrotnie zabierany z ulicy i poddawany przesłuchaniem w miejscowym KGB bez formalnego aresztowania. Takie były metody działania władz sowieckich.

Trwało to pięć miesięcy. To nie jeden dzień, nie dwa i nie jedna noc. Idę ulicą, samochód dogania mnie, drzwi się otwierają, łapią za rękaw, wciągają do samochodu i zabierają na noc. Tu, w Pińsku siedziałem. Całymi nocami w KGB, te pięć miesięcy. O świcie, o piątej, szóstej rano wychodziłem, jak błędny szedłem drogą. Tam, gdzie wtedy mieszka$\mathfrak{l e m}^{78}$, u pewnej staruszki, to sąsiedzi przychodzili do tej staruszki i mówili: „Jakiego wy wzięliście na mieszkanie człowieka? Przecież w nocy nie można spać. On wrzeszczy na cały głos”. W nocy odtwarzały się mi sceny badań, tortury... Ja we śnie nie chciałem tego. I kiedy budziłem się, to byłem mokry, od takiego zimnego, lodowatego potu... Dłuższy czas sobie uświadamiałem, gdzie jestem: o nie, Boże, to śnię, nie, nie, nie..., ja przecież już wolny jestem. Czasem tak... Staram się nie myśleć o tym, a później tak myślę: może to już i nieprawda, może to legenda... $\mathrm{Nie}$, to jednak prawda, nie legenda. To twarda prawda ${ }^{79}$.

Wielokrotnie grożono ks. Świątkowi ponownym zesłaniem na Syberię. Ale jak wspominał, odpowiadał, że „w Związku Sowieckim są trzy kategorie ludzi: ci, co siedzieli, ci, co siedzą i ci, co będą siedzieć. To pierwsze ja mam za sobą, przed wami jeszcze wszystko"80. Brał jednak pod uwagę perspektywę ponownego zesłania na Syberię. „Moją wolność traktowałem, jako rodzaj urlopu, który w każdej chwili może się skończyć"81.

Po miesiącach szykan, wobec nieugiętej postawy władze sowieckie oficjalnie postanowiły uznać Kazimierza Świątka jako księdza

$76 \quad$ Kopia pisma w archiwum prywatnym ks. kard. K. Świątka (APKS).

APSK, zapis rozmowy autora z ks. kard.K. Świątkiem przeprowadzonej w czerwcu 2002 r., mps. Datę zarejestrowania potwierdza tzw. Sprawka (zgoda na pracę w parafii) nr 59 wystawiona w Brześciu 21 marca 1962 r., gdzie podana jest data rozpoczęcia pracy: 1 grudnia 1954. Oryginał w APKS, fotokopia w APSK.

Ksiądz K. Świątek mieszkał wówczas w Pińsku przy ulicy Piaskowej (Pieszczannaja) 6.

APSK, zapis rozmowy autora z ks. kard. K. Świątkiem, mps.

APSK, zapis rozmowy autora z ks. kard. K. Świątkiem, mps.

APSK, zapis rozmowy autora z ks. kard. K. Świątkiem, mps. Por. K. Renik, Podpolnicy, op. cit., s. 212. 
mającego prawo pracować w parafii. „Pierwszego grudnia 1954 roku wezwali mnie do Brześcia do Obispatkoma ${ }^{82}$. Wręczają sprawkę rejestracyjną, podają rękę: «Pozdrawlajem ${ }^{83}$. Od jutra formalnie zaczynajcie duszpasterzowanie (służbu) w katedralnym kościele»"84.

Tak zaczęła się oficjalna praca ks. Kazimierza Świątka w katedrze pińskiej.

Gdy ks. Kazimierz Świątek rozpoczynał pracę duszpasterską w Pińsku najbliższe czynne kościoły znajdywały się w Brześciu, Baranowiczach, Różanie i we Lwowie. Przez kilkadziesiąt lat przybywali do Pińska wierni z obwodu homelskiego i innych rejonów wschodnich Białorusi oraz z dalszych stron na wschodzie, gdzie często od lat dwudziestych XX wieku nie istniała żadna opieka religijna. Najbliższy kościół katolicki w kierunku wschodnim był w Moskwie (jego rola duszpasterska była jednak znikoma, gdyż władze sowieckie zgodziły się na jego funkcjonowanie, tylko jako kościoła dla dyplomatów akredytowanych w Moskwie).

W miarę swoich możliwości piński proboszcz starał się otoczyć wszystkich opieką duszpasterską.

Często z Mińszczyzny do mnie przejeżdżali. Na pogrzeby jeździłem do 250 kilometrów od Pińska. Dalej nie, bo za czym pojadę i wrócę, to tu dwóch czy trzech może umrzeć, bez spowiedzi, bez Komunii świętej. Do chorego to jechałem i dalej. Dwieście, trzysta kilometrów z Panem Jezusem jechałem. Autobusem, pociągiem, furmanką, bo przecież nie miałem samochodu. A w Pińsku przyjmowałem wszystkich, którzy się zgłosili ${ }^{85}$.

W czasach sowieckiego terroru byli odważni ludzie, którzy chodzili zawsze do kościoła, nie ukrywali swej wiary, często płacili za to wysoka cenę. Jednak wielu parafian ks. Kazimierza Świątka ze strachu przed represjami, ze strachu przed utratą pracy, stanowiska, mieszkania nie chodziło do kościoła. Ale nie przestawali wierzyć w Boga, w ukryciu, w tajemnicy jednak się modlili. Ksiądz Świątek, tak nieugięty, odważnie wyznający swoją wiarę i płacący ogromną cenę za wierność Chrystusowi, wykazywał wielką wyrozumiałość dla słabości innych.

Tych ludzi nigdy nie potępiłem, nigdy nie wyrzucałem im, że stchórzyli.

To prawda, że nie starczyło im odwagi, by publicznie w tych strasznych

82 Obispałkom: Obwodowyj Ispotnitielnyj Komitiet, Wojewódzki Komitet Wykonawczy, Urząd Wojewódzki w ZSRS.

83 Gratulujemy.

84 APSK, zapis rozmowy autora z ks. kard. K. Świątkiem, mps.

APSK, zapis rozmowy autora z ks. kard. K. Świątkiem, mps. 
czasach wyznawać wiarę. Ci ludzie, nie ukrywali swej wiary z własnego wyboru. Nie, oni chcieli wierzyć, ale też chcieli jakoś żyć, chcieli utrzymać się. Modlili się w tajemnicy, wierzyli w tajemnicy, ale publicznie nie wypierali się wiary, nie wypierali się Chrystusa. Tu każda osoba wymagała odrębnego potraktowania, bo sytuacje były bardzo różne

- mówił ks. kard. Kazimierz Świątek ${ }^{86}$.

Proboszcz piński przez trzydzieści sześć lat swej posługi kapłańskiej robił wszystko, co było możliwe, aby umocnić w wiernych wiarę, często słabą, pełną rozterek i strachu, ale jeszcze się tlącą. Wierzył głęboko w Boga i Jego miłosierdzie, a w jego pastoralnej posłudze najważniejsze było zawsze „trwanie na tej ziemi Kościoła Chrystusowego"87. Sił dodawała mu jego dewiza życiowa: „Jaki Pan Bóg jest dobry” i wiara w pomoc Ducha Świętego, do którego modlił się codziennie ${ }^{88}$. Nigdy nie zwątpił, że komunizm upadnie. „Wewnętrznie byłem przekonany, że ten system się nie utrzyma, że dobry Bóg na to nie pozwoli" ${ }^{89}$.

Z każdym rokiem było jednak coraz mniej kapłanów na Białorusi. Ksiądz Kazimierz Świątek odprowadzał ich na wieczny spoczynek.

Byłem cmentarnym księdzem wszystkich księży. Wszyscy mi umierali. Jeden po drugim. A gwardia to była... Jeden w drugiego. Niemal wszystkich kolegów pożegnałem na cmentarzach. Byłem takim... mówcą pogrzebowym ${ }^{90}$.

Pomimo tego, że odchodzenie kapłanów do Pana rodziło wśród wiernych niepokój i ból, pogrzeby wykorzystywał proboszcz piński do umacniania wiernych i budzenia w nich wiary w Bożą Opatrzność. 22 sierpnia 1986 roku w czasie pogrzebu ks. Jerzego Rosiaka, proboszcza w Połoneczce, który zginął w tajemniczym wypadku drogowym, ks. Kazimierz Świątek wołał, przerywanym ze wzruszenia głosem:

APSK, zapis rozmowy autora z ks. kard. K. Świątkiem, mps.

APSK, na podstawie rozmowy autora z ks. kard. K. Świątkiem, mps.

APSK, zapis rozmowy autora z ks. kard. K. Świątkiem, mps: „Nie ma dnia, żebym nie zwracał się do Ducha Świętego. (...) I przy zaczynaniu każdej sprawy kościelnej i sprawy osobistej ważniejszej zaczynam od Ducha Świętego. Veni creator Spiritus... I wtedy idę. Idę do prezydenta, idę do wojewody, idę na milicję. A w KGB na każde przesłuchanie, to ja z Duchem Świętym szedłem. Biedni ci ludzie, którzy tego nie mają. Niektórzy nawet nie wiedzą, że Duch Święty istnieje. Ze swojej czy nie swojej winy. Ja miałem to szczęście, że mama nauczyła mnie tego".

89 APSK, rozmowa autora z ks. kard. K. Świątkiem; por. też Pasterz - Kardynat Kazimierz Świątek, film dokumentalny, reż. S. M. Królak, P. Woldan, TVP SA 2002.

$90 \quad$ APSK, zapis rozmowy autora z ks. kard. K. Świątkiem, mps. 
Historia Kościoła

Tu, jako chrześcijanie, jako katolicy powinniśmy głowę skłonić przed niezbadanymi wyrokami Opatrzności Bożej. Nie nasza, ale Boża wola nich się stanie. I stała się. Dziękujemy Ci księże Jerzy. Wszyscy, bez wyjątku. I jednocześnie przepraszamy Cię za to, że może nie raz nie usłuchaliśmy Twego głosu nawołującego do Boga, do Kościoła, do sakramentów świętych. Przepraszamy Cię za to. I jednocześnie teraz na znak naszej wdzięczności obiecujemy i ślubujemy przy Jego trumnie i Jego mogile, że odtąd będziemy zawsze i wszędzie niezależnie od niczego i nikogo, będziemy zawsze wiernymi wyznawcami Boga. Będziemy! Będziemy zawsze wierni Kościołowi katolickiemu! Będziemy! Będziemy zawsze przestrzegać wszystkie przykazania Boże i kościelne. Będziemy! Będziemy słuchać swych duszpasterzy! Będziemy! ${ }^{11}$

Odejścia do Boga kapłanów i świadomość, że wierni mają coraz bardziej utrudniony dostęp do Eucharystii i sakramentów, także u ks. Kazimierza Świątka wyzwalała emocje.

Mój sąsiad ksiądz Stanisław Ryżko. Chyba 27 lat pracowaliśmy razem, on w Łagiszynie, ja w Pińsku. Pamiętam ubrany byłem na biało w kościele, gdy przyjeżdża kierowca z Łagiszyna i mówi: „Proszę księdza dziś ksiądz proboszcz umarł". Znalazłem jakiś samochód, przyjeżdżam. Położyli go w tym jego pokoiczku, takiej izdebce. Leży mój Stanisław spokojnie. Podchodzę, patrzę na niego. Upadłem na kolana, pochyliłem głowę do jego głowy i jakoś tak wzburzyłem się cały. Wziąłem go za ramiona i mówię: „I co ksiądz najlepszego przemyślał? Co najlepszego ksiądz zrobił? Umarł ksiądz! To najprostsze wyjście. Trzeba żyć, trzeba pracować. A on wziął i umarł”. I nagle tak, jakbym usłyszał: „Patrzaj żebyś sam nie zwariował przy tym trupie". I wtedy się opamiętałem ${ }^{92}$.

Opamiętał się i nadal pełnił swą posługę kapłańską dla wszystkich wyznawców Chrystusa i na świadectwo dla Jego nieprzyjaciół. W pińskiej katedrze pracował nieprzerwanie jako proboszcz 36 lat, 4 miesiące i 13 dni. Nie lubił, gdy nazywano go bohaterem, męczennikiem i świadkiem wiary. Swoją postawę uważał za naturalną. Uważał, że chrześcijanin, zwłaszcza w chwilach próby, winien być wierny Chrystusowi.

Owszem przetrzymałem te więzienia i łagry, dochowałem wierności Chrystusowi. Ale to nie było męczeństwo, ani bohaterstwo. Ci, co tu na

$91 \quad$ APSK, zapis mowy wygłoszonej przez ks. K. Świątka na pogrzebie ks. J. Rosiaka w Połoneczcze 22.08.1986 r., mps, por. Fidei testis - Świadek wiary, film dokumentalny, reż. J. Goruliow, prod. Studio „Stopkadr” 2009.

92 APSK, zapis rozmowy autora z ks. kard. K. Świątkiem, mps, ks. Stanisław Ryżko zmarł 1.12.1984 r. 
Białorusi tak mówią, to chcą sami się usprawiedliwić. To było zwykłe codzienne, wypełnianie swojego obowiązku ${ }^{93}$.

W latach 1961-1986 ks. Kazimierz Świątek odrestaurował, pomimo wielu trudności materialnych i nie tylko, historyczną katedrę w Pińsku (dawny kościół pofranciszkański, początkami sięgający 1396 roku), osobiście pracując fizycznie nad jej renowacją. „Tu przydało mi się to, czego nauczyłem się, budując miasto Inta"94 - mówił śmiejąc się. Wkrótce po objęciu katedry rozpoczął remont. Zaczął od dachu, bo prawie go nie było. W zamian za blachę ocynkowaną otrzymał dachówkę z jednego z kościołów spod Grodna i tą dachówką, jeszcze dziewiętnastowieczną pokrył dach. Później skuł stare tynki zewnętrzne, zrekonstruował i pokrył nową blachą chełmy i krzyże na dachu, wymienił całą blacharkę. Kolejnym etapem miała być renowacja wnętrza. I wówczas nastąpił kontratak miejscowych władz partyjnych. Postanowiły one zamknąć kościół i odebrać go wiernym. Jednak ze względu na opór wiernych same nie były w stanie tego zrobić i zwróciły się o decyzję do Moskwy, argumentując, że katolików w Pińsku jest mało i że to ks. Świątek nadzoruje remont kościoła, a nawet osobiście go maluje, przywraca na nim krzyże i inne elementy architektury religijnej, przez co „nadaje miastu charakter polsko-katolicki”. Po przejęciu kościoła władze zamierzały urządzić w nim... browar. Jednakże i tym razem postawa wspólnoty katolickiej z ks. Kazimierzem Świątkiem na czele, udaremniła te plany. Świątynia została wpisana na listę zabytków, a wnętrze odzyskało dawny blask.

11 lutego 1988 roku Stolica Apostolska obdarzyła ks. Kazimierza Świątka godnością Kapelana Jego Świątobliwości ${ }^{95}$.

7 września 1988 roku gościł on w Pińsku Prymasa Polski ks. kard. Józefa Glempa przebywającego po raz pierwszy z oficjalną wizytą w ZSRR.

11 kwietnia 1989 roku bp Władysław Jędruszuk z Drohiczyna, administrator diecezji pińskiej, mianował ks. Kazimierza Świątka

93 APSK, zapis rozmowy autora z ks. kard. K. Świątkiem, mps. Por. Pasterz - Kardynat Kazimierz Świątek, film dok., reż. S. M. Królak, P. Woldan, prod. TVP SA 2002.

94 APSK, zapis rozmowy autora z ks. kard. K. Świątkiem, mps.

95 APKS, taką datę nosi pismo nominacyjne Sekretariatu Stanu Stolicy Apostolskiej, które zostało przesłane do bpa W. Jędruszuka w Drohiczynie. Biskup Jędruszuk powiadomił ks. K. Świątka o otrzymanej przez niego godności pismem z 5 lipca 1988 r. załączając pismo ze Stolicy Apostolskie. Kopie obu pism w APSK. 
Historia Kościoła

wikariuszem generalnym diecezji pińskiej na obszarze ZSRS ${ }^{96}$. Nominację tę potwierdził następnie biskup katolików na Białorusi Tadeusz Kondrusiewicz.

13 kwietnia 1991 roku Jan Paweł II mianował go arcybiskupem nowo utworzonej metropolii mińsko-mohylewskiej obejmującej całe terytorium Białoruskiej Socjalistycznej Republiki Sowieckiej. Nowy metropolita został równocześnie administratorem apostolskim diecezji pińskiej ad nutum Sanctae Sedis ${ }^{97}$. Nowy metropolita miał 76 lat. Zgodnie z kanonami KPK biskup po osiągnięciu 75. roku życia składa rezygnację z pełnionej funkcji. We wtorek 21 maja 1991 roku w pińskiej katedrze ks. Kazimierz Świątek przyjął sakrę biskupią. Głównym konsekratorem był abp Tadeusz Kondrusiewicz z Moskwy, współkonsekratorami: bp Władysław Jęrduszuk ${ }^{98}$ z Drohiczyna, bp Edward Kisiel ${ }^{99}$ z Białegostoku oraz nuncjusz apostolski w Związku Sowieckim abp Francisco Colasuonno.

96

APSK, na podstawie zapisów w kalendarzu prywatnym ks. K. Świątka. Dekret nominacyjny w APKS.

Zob. Secretaria Status, Pontificia Commisio pro Russua, Provisio Ecclesiarum, „Acta Apostolicae Sedis - Commentarium Officiale”1991, nr 7, vol. LXXXIII, s. 601. W kalendarzu prywatnym ks. K. Świątka pod datą 13 kwietnia 1991 jest zapis: „12.00 Grodno!!!! Abp. Metrpolit. M-M, Adm. Ap. Diecezji pińskiej”. Jednakże, jak się wydaje, proces nominacji był nieco bardziej złożony. W Żytomierzu 3 marca 1991 roku ks. K. Świątek dowiedział się od nuncjusza apostolskiego w ZSRS F. Colasuonno, że zostanie biskupem pińskim. 6 marca 1991 r. w Grodnie wyraził pisemnie zgodę na przyjęcie sakry. 25 marca w Grodnie dowiedział się, że zostanie biskupem pińskim i administratorem Archidiecezji Mińsko-Mohylewskiej i wyraził zgodę. Wreszcie w Wielki Czwartek 28 marca otrzymał list informujący go, że zostanie Metropolitą Mińsko-Mohylewskim i administratorem diecezji pińskiej. 2 kwietnia wyraził w Grodnie pisemnie zgodę na tę ostatnią propozycję. W APKS, w kalendarzu prywatnym ks. K. Świątka pod odpowiednimi datami są zapisy: „Grodno I, Grodno II, Grodno III, zgoda.” Na podstawie kalendarza prywatnego ks. K. Świątka i zestawienia najważniejszych wydarzeń w roku 1991 sporządzonego dla autora niniejszej pracy przez JEks. kard. K.Świątka, APSK.Zmiany stolic biskupich wynikały,jak się wydaje z postępów rozmów z władzami sowieckimi, które musiały wyrazić zgodę na nowe struktury kościelne i nominacje biskupie.

Władysław Jędruszuk (1918-1994), w latach 1962-1967 bp pomocniczy w Drohiczynie ze stolicą tytularną Clysma, 1967-1991 administrator apostoli diecezji pińskiej z siedzibą w Drohiczynie, 5 czerwca 1991 mianowany pierwszym biskupem diecezji drohiczyńskiej. Por. P. Nitecki, Biskupi Kościoła w Polsce w latach 965 - 1999: stownik biograficzny, Warszawa 2000, s. 184.

Edward Kisiel (1918-1993), bp tytularny Limaty i administrator apostolski archidiecezji wileńskiej z siedzibą w Białymstoku w latach 1976-1991, 5 czerwca 1991 mianowany pierwszym biskupem diecezji białostockiej, 25 marca mianowany arcybiskupem metropolitą białostockim. Por. P. Nitecki, Biskupi..., op. cit., s. 202-203. 
Na konsystorzu w dniach 26-27 listopada 1994 roku, Jan Paweł II powołał ks. abp. Kazimierza Świątka do kolegium kardynalskiego.

14 czerwca 2006 roku Benedykt XVI przyjął złożoną przez ks. Kardynała rezygnację z urzędu Metropolity Mińsko-Mohylewskiego. Nadal pełnił posługę w diecezji pińskiej, jako jej administrator apostolski.

Energii i pasterskiego wigoru ks. Kardynałowi nadal nie brakowało. Niestety wiosną 2010 roku na skutek upadku w łazience złamał staw biodrowy. Konieczna była operacja. Została przeprowadzona w szpi- Kościoła talu uniwersyteckim w Lublinie. Tam też ks. kard. Świątek poddał się kilkumiesięcznej rehabilitacji. W tym czasie starał się kierować diecezją poprzez codzienne konferencje telefoniczne $\mathrm{z}$ kanclerzem Kurii i innymi współpracownikami. Jak mówił „diecezja nie straciła pasterza, panuję nad sytuacją"100.

Po powrocie do Pińska podjął normalne obowiązki. W marcu 2011 roku złamany staw biodrowy ponownie dał znać o sobie. Konieczna była kolejna operacja. Chciał jechać do Lublina, ale ostatecznie znalazł się w szpitalu w Pińsku. Przeszedł operację. Tym razem pojawiły się poważne komplikacje, a stan zdrowia bardzo się pogorszył. Potem cierpiał - bardzo cierpiał przez wiele miesięcy.

30 czerwca 2011 roku Benedykt XVI odwołał przebywającego w szpitalu w Pińsku ks. kard. Kazimierza Świątka z funkcji administratora apostolskiego diecezji pińskiej.

21 lipca 2011 roku w szpitalu w Pińsku, dokładnie na 3 miesiące przed ukończeniem dziewięćdziesięciu siedmiu lat, pierwszy Metropolita Mińsko-Mohylewski, pierwszy kardynał w historii Kościoła katolickiego na Białorusi, ks. Kazimierz Świątek odszedł do Pana po przygotowaną dlań nagrodę.

25 lipca na placu przed pińską katedrą zgromadziły się liczne rzesze wiernych na uroczystej Mszy św. pogrzebowej, której przewodniczył, jako legat papieski, metropolita krakowski kard. Stanisław Dziwisz. Po Mszy św. trumna z ciałem księdza kard. Kazimierza Świątka złożona została w krypcie w podziemiach pińskiej katedry. W tej samej krypcie w 1932 roku był pochowany bp Zygmunt Łoziński.

\section{Zakończenie}

Ksiądz Kazimierz Świątek poddawany wielkim próbom zachował wierność Chrystusowi i kapłańskiemu powołaniu. Spośród przymiotów Boga szczególnie podkreślał Jego dobroć. Dobroć Boga sławił

100 APSK, na podstawie rozmowy autora z ks. kard. K. Świątkiem w maju 2010 r. w Lublinie. 
Człowiek, który przeszedł piekło na ziemi. W tej perspektywie otwieramy się na tajemnicę heroicznej wiary ks. Kazimierza Świątka i tajemnicą Bożego Miłosierdzia, które pozwala dostrzec dobroć Boga w sytuacjach granicznego doświadczenia. Uprawnione jest tu przywołanie Księgi Hioba, który poddany cierpieniu nie odstąpił od dwóch pewników: wiary w swoją niewinność i swej więzi z Bogiem. Zauważmy jednak, że nie była to dominująca postawa w XX wieku. Bardzo liczne w kulturze światowej XX stulecia są świadectwa ludzi, którzy przeszli przez piekło niemieckich i sowieckich obozów koncentracyjnych i zwątpili, stracili wiarę, nawet przeklinali Boga. Poszli drogą Iwana Karamazowa z powieści Dostojewskiego. Ksiądz Kazimierz Świątek - tak jak Hiob - chociaż doznał cierpienia w Boga nie zwątpił. Dał świadectwo Bogu, Chrystusowi i wierności kapłańskiemu powołaniu. Jego świadectwo pokazuje, że osobiste świadectwo uczniów Chrystusa jest niezbędne dla skutecznej ewangelizacji. Świadczy również, że także dzisiaj jest ono możliwe.

Słowa klucze: łagry, komunizm, świadectwo, wyznawca, wierność Bogu, powołanie kapłańskie, duszpasterstwo.

\section{Bibliografia:}

1. Bohdanowicz J., Mauzoleum Marszatka i cmentarz żotnierski na Rossie, Warszawa 2007.

2. Borowski E., Wyższe Seminarium Duchowne Diecezji Pińskiej 1925-1939, Drohiczyn 2000.

3. Dzwonkowski R., Leksykon duchowieństwa polskiego represjonowanego $w$ ZSRR 1939-1988, Lublin 2001.

4. Dzwonkowski R., Losy duchowieństwa polskiego represjonowanego w ZSRS 19-39-1988, Lublin 2003.

5. Dzwonkowski R., Z historii Kościoła katolickiego w ZSRS 1917-1991, Ząbki 2005.

6. Fidei testis - Świadek wiary, film dokumentalny, reż. Jurij Goruliow, prod. Studio „Stopkadr” 2009.

7. Górska M. T., Męczennice z Nowogródka, „L'Osservatore Romano” 2000, nr 2.

8. Kapłan z gułagu cz.2, reportaż telewizyjny, reż. S. Auguścik, Telewizja Polska 1990.

9. Koprowski M. A., Białoruś. Uparte trwanie polskości, Toruń 2006.

10. Nitecki P., Biskupi Kościoła w Polsce w latach 965-1999: stownik biograficzny, Warszawa 2000,

11. Pasterz - Kardynat Kazimierz Świątek, film dokumentalny, reż. S. M. Królak, P. Woldan, prod. TVP SA 2002.

12. Renik K., Podpolnicy, Warszawa 1991. 
13. Rocznik polityczny i gospodarczy 1939, Warszawa 1939.

14. Secretaria Status, Pontificia Commisio pro Russua, Provisio Ecclesiarum, „Acta Apostolicae Sedis - Commentarium Officiale” 1991, nr 7, vol. LXXXIII.

15. Socci A., Mroki nienawiści. Męczeństwo chrześcijan XX wieku. Studium nietolerancji, Kraków 2003.

16. Walichnowski T. (red.), Deportacje i przemieszczenia ludności polskiej w gtab ZSRR 1939-1945, Warszawa 1989.

17. World Christian Encyklopedia. A comparative survey of churches and re- Kościoła ligions in the modern world, vol. 1, New York 2001. 